\title{
Deixis Category as Favorable Syllabus Materials - A Critical Study in Sudan Practical Integrated National English
}

\author{
Mustafa Shazali Mustafa Ahmed \\ Nile Valley University, P.O. Box1843, Khartoum, Sudan \\ Email: mustafashazali65@gmail.com.
}

\begin{abstract}
Having synthesized many findings of studies that have recently been conducted on Sudan Practical Integrated National English (SPINE); having tried to move linguistic pragmatics to the area of applied linguistics, the researcher found that these studies' findings have unanimously attributed SPINE problems only to typing errors and the use of Sudanese culture to teach English language. By comparing random selected materials from both SPINE the current syllabus and the READERS an earlier English syllabus, the researcher attempts in this paper to provide general framework of using deixis as a pragmatic inference as a helpful item in deciding and revitalizing the syllabus materials writing process which is considered as the most important stage of curriculum development. Considerable number of studies in syllabus design have viewed language learning through the 'subject' or knowledge offered by the given materials, how these materials account for ways in which teachers and learners interact with each other, how materials develop problem-solving abilities, and to what extent materials can transmit to the learners attitudes and values presented in the syllabus texts . The present study, however, investigated four aspects in both the aforementioned syllabi. Those are the number of paragraphs in each syllabus, the mechanism of sentence functional perspective, error and mistakes, and the structuring of deixis category in the two mentioned syllabi. The study has arrived at that it would be possible for English language syllabus designers in general to predict, and for SPINE designer in particular to have predicted proximate guides of what the EFL students will learn if the mentioned areas are seriously considered.
\end{abstract}

Index Terms - deixis, materials, curriculum development

\section{INTRODUCTION}

Deixis in English is represented by person pronouns, demonstratives, tense, specific time and place adverbs like 'now', 'here', and other features of grammar held tightly to the circumstances of utterance. Deixis or 'indexical expressions' lie within the border of pragmatics and semantics. To put it another way, 'pragmatics' main function is to catch the evasive meaning of language which cannot be traced in a truth - conditional semantics as pointed out by (Levinson, 1983, P. 58) in following examples:

1/ John Henry Mc Cavity are six feet tall and weigh 200 pounds.

2/ John Henry Mc Cavity are six feet tall.

3/ I am six feet tall and weigh 200 pounds.

4/ I am six feet tall.

It is clear from the above examples that if (2) and (4) are valid inferences from (1) and (3) they must be said by the same speaker, that is to say the speaker who describes 'John' and the speaker 'I'.

Here (Levinson, 1983) relates 'logic' to contexts of utterance. Because sentences as indicated by (Francis \& Dinesen 1967, P 360) always underlie different propositions on different occasions. Levinson (1983) also indicates that the reference in the above sentences will be valid only if the speaker index and the time index are tied together.

It becomes clear from this approach that sentences in their abstract can be glossed as vague and meaningless, and do not express specific propositions at all. There are only utterances in specific contexts that negotiate definite states of affairs. One of the aspects by which Levinson draws a clear cut boundary between sociolinguistics and pragmatics is the category of social deixis. To put it another way he restricts this category of deixis to the study of facts that lie in the scope of structural studies of linguistic systems. He also shows that it disambiguates the social identities and the relation between participants. He adds that such following examples can be true only if they are indeed identical to the individual who is the mother of Napoleon and false otherwise.

1/ I am a mother of Napoleon.

2/ Eliza de Rambling was the mother of Napoleon.

3 / you are the mother of Napoleon.

\section{A BRIEF REVIEW LITERATURE}


Making use of a philosophically oriented deixis, the writer of this paper conceives a pedagogically oriented aspect of deixis whose potential meaning could help reconcile between what is called the structural syllabus and the notional syllabus. Potential meaning defined by Holliday, quoted in (Widdowson, 1979, P.249), as that the form itself contributes to the meaning process. Here, it is better to pedagogically perceived (Ariel's,2008, P.343) three forces behind grammar, namely, cognition, socio -cultural norms and pragmatic inferences. It is also important to pedagogically contemplate (Cooren's, 2010) logic of configuration that is as he mentioned can be found in any type of interaction, a debate, a dialogue, a conversation, etc. He mentioned that arguing for or against something consists of implicitly staging figures that are suppose to support the position one is putting forward regarding specific topic. He shows that those figures can be facts, principles, persons, traditions, institutions, expertise, knowledge, documents etc and interactants in a given conversation usually animate or ventriloqualize those figures explicitly or implicitly. Here it better also to mention (Mustafa's, 2011, P. 68) conceptualization of presupposition inference and how it motivates language users to fit in their ideas in order to extend and adjust the discourse the interlocutors are in. It can be said that both Cooren's mentioned figures and Mustafa's notion of presupposition as a mechanism that generates and extends the discourse by relatively bringing the necessary support may include the notion of deixis categories and they should fully be regarded in the selection of syllabus writing of materials. The paper also makes use of (Kaplan's, 1989) two sorts of indexical which are' character' (or linguistic meaning), and' content'. Using these two conceptions in teaching process, teachers could easily help their students differentiate between for example the word 'I' in the sentence' I am a female' knowing that it has a single character (or linguistic meaning), but it may also have different contents in different contexts.

\section{A. Person Deixis}

It looks for the encoding of the role of participants or pronouns and their associated predicate agreements in the speech event. That is speaker's reference to himself (first person), speaker's reference to one or more addressees (second person); and the encoding of reference to persons and entities which are neither speakers nor addressees of the utterance in question (third person). Levinson (1983) symbolizes for first person $(+\mathrm{s})$ which means speaker's inclusion; and for second person $(+\mathrm{A})$, which indicates addressee's inclusion. And for third person (-S, $-\mathrm{A})$ which means speaker's and addressee's exclusion since this third type does not refer to any participant role in the speech event. For example the pronoun 'we' has a potential for ambiguity i.e. between exclusive 'we' which (excludes the hearer) and the hearerincluding (inclusive) 'we'. He further states that deictic usage of this centre appears in pronouns, vocatives and greetings. But although pronouns are commonly used not deictically, there are some natural uses which cannot easily be captured. Example of that is provided by (Fillmore, 1971) of the editorial 'we' of the New Yorker. That is although it takes plural verb agreements (thus we are not we am), it appears in the proceeding text of the same editorial with reflexive singularity in phrases like 'for ourself'. Another example is provided by Levinson of the hostess who announces in an air - flight something like the following:

- You are to fasten your seat-belts:

He indicates that in order for someone to understand such utterance, there must be a distinction of speaker from source of information, and the addressee from the target. Levinson further shows that person role is marked in many ways. He shows that title and proper names often come in two sets. One is used in address as vocative in second person usage. Example of this is the following:

- Hey you, you just scratched my car with your Frisbee:

And the other way is used in reference (i. e referring to individuals in third person role). Example of this type is the following.

- The truth is, Madam, nothing is as good nowadays.

He also provides an example of proper names in a situation of a mother who says to the father in the presence of the little Billie something like the following.

- Can Billie have an ice-cream Daddy?

In the above example, he notes that there must be clear-cut distinction between addressee and hearer. He further states that where face to face is lost e.g. 'I am Joe Blogs, language instead tends to introduce itself e. g. in a phone conversation 'this is Joe Blogs.

\section{B. Time Deixis}

Time deixis encodes point and spans relative to the time at which an utterance is spoken. An essential point to be mentioned here is (Fillmore's, 1975) classification of time into coding time 'CT' (the time at which the speaker produces in hislher utterance). And receiving time 'RT' of the addressee to the particular code or message. It is important to note that time deixis is central for texts to be meaningful since 'language always wears its time'. Therefore, the word 'now', for example, can be glossed as the time at which the speaker is producing the utterance containing it that is the notion of Coding Time 'CT'. Time deixis can also interact with cultural measurements of time in non deictic way. For instance 'today' can be considered as 'the diurnal span including CT, Yesterday', however, can be conceived as 'the diurnal span preceding the diurnal span that includes CT (Levinson, 1983, P. 75).

He proceeds to show that in the application of 'next' to cylindrical names of days an ambiguity may arise. For instance 'next Thursday', can either be referred to as the Thursday of the week that succeeds the week that includes 'CT', or that Thursday that first follows the 'CT'. 
Complexities also may arise in this deictic centre of time in the usages of tense, time adverbs, and other time deictic morphemes. For instance (Levinson, 1983) states that in letter writing, or pre-recording of media programmed that a decision has to be made of the time, whether Coding Time ' $\mathrm{CT}$ ', or receiving one (to be projected in the addressee RT). (Fillmore's, 1975) examples illustrate this phenomenon.

- This programmed is being recorded today - --Wednesday April $1 \mathrm{~s} \mathrm{t}$, to be relayed next Thursday.

- This programmed was recorded last Wednesday April I s t, to be relayed today.

As noted above, deictic time adverbs like 'now', 'then', 'soon', 'recently' so on, can be conceived pragmatically by the given span including CT. (Harris, 2005) shows how temporal adverbs help support students' memory and reduce tense shifting. Harris' experiment shows that $45 \%$ of the sentences given to the tested students were recalled with shifts in the verb tense and this shift appeared to be due to lack of temporal adverbs. Harris' study concludes that verb tenses either the present, past, future, present perfect, past perfect, or future perfect tenses are relatively meaningless without a temporal deictic context. This time span as indicated by (Levinson, 1983) may be the instance associated with the production of the morpheme itself as in the gestural usage in (1) or perhaps in the interminable period indicated in (2).

1/ Pull the Trigger now. 2/ I' m now working on a ph. D

\section{Place Deixis}

Place deixis is concerned with the encoding of spatial locations relative to the location of the participants in the speech event. Examples of this proximal deictic place and distal one can be conceived in demonstratives 'this' and 'that' and deictic adverbs 'here' and 'there'. This category of deixis always incorporates a covert time deixis element, while the converse is not true (Levinson, 1989, P. 58). Places as physical entities can deictically be identified in relation to the location of the participants at the time of speaking as in the following examples.

- It's two hundred yards away.

- Kabul is four hundred miles west of here.

\section{Discourse Deixis}

Discourse (or text) deixis primarily concerns the expressions within some utterance to refer to some portion of the discourse that contains that utterance. Therefore, discourse deixis has a sense of reference being anchored to its location of the current utterance. For instance utterance initial 'anyway' seems to indicate that the utterance which contains it is not addressed to the immediate preceding discourse, but to one or more steps back (Levinson 1989, P. 85) Levinson also made a clear-cut distinction between discourse deixis and what is called 'anaphora'. He relates a pronoun in the former to a linguistic expression (or chunk of discourse). Anaphoric expressions always relate the pronoun of the same entity as a prior linguistic expression. Older rhetoricians divide discourse in four types indicated by (Davidson, 1964, P.39) as exposition, description, narration, and argument. (Levinson, 1983) assumes that utterance initial usages of 'but', 'therefore', 'in conclusion', 'to the contrary', 'still,' 'however', 'anyway', 'well,' 'besides', 'actually' all in all,' 'so', 'after all' etc, can pragmatically be interpreted as having discourse communicative values. This can be done as how the utterance contains them is considered as actual response to, or a continuation of some portion of the prior discourse. That is prior explaining, describing, narrating, and arguing which are considered as intricate issues when selecting for example particular materials for particular syllabi or pedagogical teaching situations and learning activities should be considered.

\section{E. Social Deixis}

Social deixis always encodes aspects of social relationship between speakers and addressees, and the social distinctions that are relative to participants' roles in speech event. This social relation in every language has specific spatiotemporal, socio-political, and cultural dimensions which are intuitively employed by the interlocutors of that particular language to show their presuppositions and the dimensions of the discourse they have been involved in. Here arises the following questions; does social deixis category with that sense allow syllabus designers to materialize English syllabus on a different culture? To what extent have evidence- based practices of English language syllabi of non -natives synthesized that issue of deixis? How to identify 'best practices' or scientifically based methods on this linguistic aspect? How do syllabus designers encourage classroom educators to use the research findings of this linguistic field? However, this category of deixis in English language is best glossed by Brown and Levinson (1978) as the language structure which contains social identities of participants and their relations. (Levinson, 1983) provides an example on 'polite' pronouns and title of address and honorifics show that they cannot be treated unless social deictic values are available. He also states that all social deixis and most aspects of discourse deixis lie beyond the scope of a truth - conditional semantics. He restricts the study of social deixis to the study of facts within the scope of structural studies of linguistic system. He further points out two kinds of socially deictic information in languages around the world. That is relational and absolute and he quotes (Irvine, 1979) and (Fillmore, 1975) for further details. Deixis category is considered as essential part in pragmatic interpretation. The basic five categories of deixis has one deictic centre which includes the central person (speaker).The central time (when the speaker produces the utterance).The central place (where the speaker's location at CT). Discourse centre is the point which the speaker is currently at in the production of his utterance. Social centre is the speaker's social status and rank to which the rank or status of the addressee or referents is relative. It is worth noting that these five categories of deixis, mentioned above, should be considered as having one deictic centre which anchored upon the speaker at CT. They also help identify the referents of referring expressions through its special 
or temporal relationship with the situation of the utterance (Harford \& Healy, 1993, P. 64). Referring expressions as indicated by (Searle 1969:P. 27) are expressions that serve to identify any thing; process, event or any other kind of individuals. They provide answers to questions who? What? Which? And they are known by their functions. The conception of proposition on the other hand has been conceived as any aspect of the meaning of the stretch of language, whether derived from what is actually said, or from what hearers assume or infer. Many other linguists define it as that part of the meaning of the utterance which describes some state of affair. So it can be said that both primary deixis (exospheric deixis), and secondary deixis (endophoric deixis) serve the context surrounding an utterance and the contextual use of deictic expressions in a particular utterance. That is deixis categories help specify the referring expressions of any written or spoken discourse and this reason which makes deixis categories revitalize English language syllabi materials.

\section{METHODOLOGY}

A content analysis design is employed for this study through carefully counting paragraphs and specifying deictic expressions of two paragraphs in some texts taken randomly from Sudan Practical Integrated National English (SPINE). It is an integrated series of six textbooks for the use of both the basic level where book 1,2,3, are taught from grade five to grade eight, and in the secondary level where book 4, 5, 6, are taught from the first year to the third final year. The study attempts to show how far deixis categories help text linguistics which is considered as an analysis of texts that extends beyond the traditional concept of sentence level and considers the communicative constraints of the situation. Counting paragraphs and specifying deictic expressions of two paragraphs are also followed in some texts taken from new method READERS an earlier Sudanese school curriculum by Michael West. Randomization process is conducted by numbering both types of the books serially to assign the units of SPINE and the Lessons of the READERS. The process of randomization ends by selecting SPINE Book 2 (Unit 3), and READERS book 2, (Lesson 3) from a random table. The main hypothesis of this study is that deixis categories help launch and sustain the foreign language learners' written and spoken discourse. Deixis categories are not fully considered upon the design of SPINE series. The aforementioned hypotheses have been raised by the following questions:

1. Does deixis category as syllabus materials help expand students' learnability?

2. Piecing together findings from a number of studies is a system usually used by organizations and professionals to collect and synthesize research-based practices. Do the writers of SPINE materials consider the latest issue of linguistic pragmatics and what is currently synthesized on deixis category as an important element in discourse analysis theory?

\section{Data Collection Procedure}

An unobtrusive observation (syllabus documentary analysis) was applied to Sudan Practical Integrated National English which is currently being taught and the syllabus of READERS which has earlier been taught in Sudan. Four aspects were investigated in both types of syllabuses. The number of paragraphs in each book, functional sentence perspective or topic-comment relation, errors and mistakes, and how far deixis categories have adequately been selected by the designers of SPINE. The ultimate aim is to provide a scientific base for considering and moving research on linguistic pragmatics to practice which in this case may be syllabus design and curriculum studies.

\section{RESULTS}

\section{A. The Number of Paragraphs}

Counting the number of the paragraphs in SPINE book 2,3 and the paragraphs in READERS 2,3, the researcher has come to a frightening conclusion, that is, if considering the number of words and the length of READERS paragraphs, it can be decidedly said that the paragraphs in READER 2,3 alone equals the whole paragraphs of the SPINE series. This can proportionally be illustrated in the following table.

TABLE 1

SHOWS A PROXIMATE GUIDE OF PARAGRAPHS IN SPINE2, 3 AND READERS 1, 2

\begin{tabular}{|l|l|l|l|}
\hline SPINE 2 & SPINE3 & READER 2 & READER3 \\
\hline 17 & 96 & 160 & 180 \\
\hline
\end{tabular}

The READERS according to what is written in their blurb constitute a seven-year course starting at the Primary School Level and are the result of carefully graded word - count. Accompanying these are Companions providing word lists and additional exercises, and composition books designed to teach how to deal in speech and writing with the material already encountered in reading. In Sudan the seven READERS were taught in the Intermediate Level which was constituted of three years and which was cancelled and been replaced by adding two additional classes to the Basic Level to become eight years rather than six years. English language teaching now begins from the fifth year of the Primary. As the above table shows that the number of paragraphs in the READERS is more than SPINE paragraphs and this is a serious indication lessening or preventing Sudanese students from exposing to the many varieties of the English Language. Exposure to the language here is a materially - thought of category which should be fully regarded when 
designing school English syllabuses as exactly done by the materials writers of READERS. It has been observed that the paragraphs of the READERS are longer and more cohesive and coherent than SPINE paragraphs.

\section{B. Functional Sentence Perspective}

(Connor 1999, P.80) illustrates that Prague School of Linguistics was the first to show how the presentation of information in whole texts should be studied along with the formal structures of sentences, such as a subject- predicate relation. (Connor, 1999) shows in western Indo- European Languages such as English, new information of one sentence in most texts becomes the topic or the old information of the next sentence. That is, new information is always introduced at the end, in the predicate. This topic - comment relation which been adequately considered in the READERS, has been severely violated in SPINE. The following are two paragraphs taken in turn from SPINE 2 (unit3) and READER 2 (Lesson 3.).

Example 1: (Taken from SPINE 2, unit3, lesson 5).

John is British. He comes from Britain. He is tall. He has got green eyes and straight hair. He is quiet and gentle, but sometimes he is very funny. Everyone likes him because he is very kind

The Unit has only three paragraphs and a dialogue for reading. The unit consists of twelve lessons. The rest of it is designed from tasks based activities and exercises ranging between ' Look and sing', 'Choose and write', 'Answer the questions,' and 'Fill in the blanks. Every paragraph of the three ones is a separate unit describing individuals, Alex lives in Nigeria, John from Britain, and Hajj Ibrahim and Hajj Musa are going to the market .The sentences following the topic sentence are not the type of functional sentence perspective mentioned earlier.

Example 2 :( Taken from READER 2, Lesson 3).

Prospero put down his book. He called Ariel." Bring the King and Antonio here," he said." My plan is ready. "Then Prospero stood up. He went out of the house. He looked to see where Ferdinand was. He looked to see where Miranda was, and what she is doing. Ferdinand and Miranda were sitting on a load of wood talking to each other.

It has been observed that in all of the READERS texts the comments or the new information of one sentence always becomes the topic or the old information of the next one and this coincides with (Connor's, 1999, P.80) conception of topic- comment relation. (Johnson, 1977, P.18) urged that at paragraph level, English course should teach the student not only to write cohesive texts, consisting of sentences which grammatically follow on from each other. He also recommends other type of sentences that follow on from each other on the level of sense as well as grammar. The texts of the READERS are that kind of texts which incorporate both types of Johnson's notions. Those texts have a high quality of novelty that satisfies the aforementioned four types of discourse mentioned earlier.

\section{Error and Mistakes in Spine}

Having synthesized twenty M.A theses conducted in Spine, the writer of this paper found that all of them have come to the same conclusions which SPINE main problem lies in typing mistakes (see the appendixes). There are also some grammatical errors in SPINE 6 in which the designers of the course have replaced the present participle with the gerund .The questions arises here what if these errors and mistakes are rectified? Will the educational authorities still keep SPINE as a national syllabus in Sudan? Will the problem of SPINE materials writing be renegotiated seriously in order to restore to the Sudanese students the much language that has unintentionally stolen from them?

\section{Deixis Category and Syllabus Materials}

The writer of this paper thinks that the potential value of each text selected as a syllabus material is to provide services of both learnability and teachability for both the student and the teacher as syllabus decision- makers in classroom implementation which is considered as the last and crucial stage of curriculum development. The ability to learn and teach English language texts requires drawing a text contours or let us name it as text geography and this can clearly be done by identifying the text's indexical words which are deictic expressions, deictic markers, and deictic words and the pro forms such as 'so' and 'do'. Even the English 'Tense' itself can be conceived as deictic. (Cormrie, 1976) states that 'tense' is described as situational- external-time and this description gives it a deictic sense since it locates the time of a situation relative to the situation of the utterance. 'Aspect' is described by (Cormrie, 1976) as situational- internal time of a verb showing a specific time distinction. What makes a paragraph smooth and interesting is the ability of the writers to gain variety by using different structures and different modifiers. The varied sentence structures can be conceived in forms such as the sentence types whether it is a simple, complex, compound or compound complex. The verbal whether it is a participle phrase, a gerund or an infinitive also add to the components of the paragraph variety. What gives the forms their spirit is the deixis category. That is deixis category is overlapped between all the mentioned forms. The interpretation of the indexical words should be glossed in relation to the speaker's location or the deixis centre. (Prabhu, 1987) argues that students' internal linguistic competence increases if the teacher abstract from any piece of language its meaning besides deploying abstracted structures that have already been formed in the teaching of new grammatical forms. For the system development (Prabhu, 1987) illustrates that every instance of deployment should constitute a step in the further development of those structures. In deploying abstracted structures, teachers need to make use of deictic expressions found in the texts or the selected materials. Abstracting structures appears in presenting vocabulary, asking questions, presenting and practicing structures, etc and all these need deixis centre to be identified by both teacher and student. If deictic expressions adequately manipulated, this will help sustain learning process and 
make text itself a pragmatic visual aid that helps much in the process of teaching. Deixis can provide input for noticing language forms and meanings. It is generally acknowledged that acquisition involves a number of processes such as noticing and reasoning and hypothesizing. (Oxford, 1990) quoted in (Hedge, 2000) divides reasoning and hypothesizing in reasoning deductively, analyzing contrastively, translating, and transferring, structuring and restructuring, and automatzing. By the term 'noticing' it is meant that language features has to be noticeable for the learners. For example they should firstly know that 'don't' used in English language to express negation, and then they can work out on the relationship between meaning and form. What makes the process of language acquisition and language learning one entity, the researcher thinks, is deixis category. Deixis serves both the form (the structural form of syllabus materials) and the meaning (functional/notional materials that incorporating communicative properties). Deixis category, the researcher believes, can however, support proponents of the argument which claims that the work on notional syllabuses should best be seen as means of developing the structural syllabus rather than replacing it (see Widdowson, 1979, P. 249). Materials writing process helps increase or decrease the use of this deixis centre. That is if the designers of a syllabus have selected much different materials, this will increase the chance of using more deictic expressions. For example, READER (7) as a whole is a story which is called 'Dead Man's Rock'. The text is so arranged that the meanings of new words can probably be guessed either from the context or by analysis of the word itself. The five deixis categories are proven to be found and this helps facilitate the process of teaching and learning of the READERS' written and spoken discourses. Discourse is to coherently make sense of what is said or read, to understand speakers or writers who communicate more than they say, and the ability to take part in that complex activity which is called conversation . The present study sees the functions of discourse analysis can easily be dealt with by the producer of the utterance and the interpreter of it only if this deixis category is well illustrated in the written or spoken discourses. The second paragraph of READER 2, Lesson 3, can be taken as an example to illustrate how personal deixis category leads the process of discourse analysis

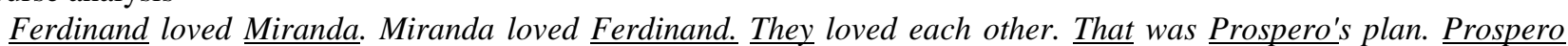

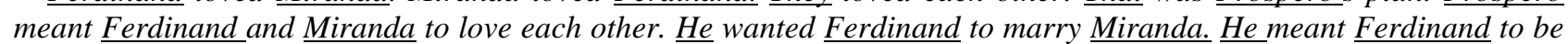
king of Naples, and Miranda to be the queen.

The underlined deictic expressions help learners notice, narrate, explain, describe and argue about what is going on in the first paragraph. For example the demonstrative 'that' has dual roles of a grammatical form and of a communicative property. The learner thus may feel secure and enjoy both the prior and the coming discourse since s/he has been given pragmatic restrictions or deictic contours to help him/ her proceed successively through the text. The teacher can also make sense of these deictic contours to develop the ability of asking questions. The questions that may be developed here like the following:

- Did Ferdinand really love Miranda?

- Did Miranda really love Ferdinand?

- Who wanted Ferdinand to marry Miranada?

- What was Prospero's Plan?

-If Prospero's plan succeed, who is going to be the king / and who's going to be the queen? In what place they are going to be king and queen?

The compared paragraph is taken from the SPINE 2, Unit 3, Lesson 5, comes as follows:

Hajj Ibrahim and Hajj Musa are going to the market. They are carrying their baskets. They want to do some shopping. Hajj Ibrahim wants to buy some meat, eggplants, onions, potatoes and bananas. Hajj Musa is going there to buy some fish, okra, cucumber, and grapefruit.

The underlined deictic expressions do not narrate, explain, describe or argue anything at all in the first paragraph. There are only few uses of personal deixis. This may lessen the teacher's ability of asking questions and student's answers will all be about Hajj Ibrahim and Hajj Musa. Paragraphs in SPINE2 are short and they do have scattered ideas, and this has lessened the teacher's ability of using deixis category appropriately.

\section{CONCLUSION}

The literature on writing syllabus materials concentrate mainly in the types of syllabuses and whether for example the particular syllabus is notional, structural, task -based or ESP one. (Widdowson, 1979, P.249) see that notional syllabus is no more than a means of developing the structural syllabus since writing materials cannot be defined as forms or functions. The present paper is, however, arrived at the importance of person, place, and time deixis categories in the process of designing materials which is considered as a crucial element in designing English language syllabi in general. The paper has tried to set forth significant policies and inputs of syllabus design. It has been proven that the English language teachers teach deixis in linguistic patterns that have been identified by (Connor, 1996, P.47-50) as textual Meta discourse and interpersonal discourse. Meta discourse are text connectives (e.g. first, next, however, but), code glosses (e.g. x means y), illocution markers (e.g. to sum up, to give example), Narrators (e.g. according to x). By interpersonal meta discourse Connor (ibid) meant the validity markers (hedges e.g. might, perhaps), (emphatics e.g. clearly, obviously), (attributors e.g. according to x), attitudes markers (e.g. surprisingly, it is fortunate that), commentaries (e.g. you may not agree on that, dear reader, you might wish to make the last section first). Reviews (Connor, 1996) said should contain indicators that an earlier text is being repeated or summarized (e.g. so far we have assumed). Previews 
on the other hand usually contain indicators that a later stage of text is being anticipated (e.g. we show below). (Morrow, 1977, P.14) defines text as 'stretch of language that is organized in some way to form a coherent whole'. He claims that the idea of text is an important one in language teaching. The present study has also reached to that SPINE series has not been built on the idea of text, while the READERS syllabus has. Chomsky's idea of competence which is the native speaker's intuitive knowledge of his language should seriously be considered and fully assigned when designing English syllabi for non natives by involving professional natives in the stages of curriculum development. Those developmental stages are ends/means specification, program implementation. That is natives should participate as needs analysts, methodologists, materials writers, and as teacher trainers to safeguard an appropriate English language curriculum for non natives speakers of English language. A unique part of native speakers' competence is their unconscious use of indexical words, and this intuitive knowledge of the indexical words may, however, help positively in writing syllabus materials for non natives.

\section{APPENDIXES}

TABLE (1)

SHOWS MISTAKES IN SPINE (2) IN GENERAL:

\begin{tabular}{|c|c|c|c|c|c|c|}
\hline No & Error & Type of mistakes & Unit & Lesson & Page & Correction \\
\hline 1 & oak & spelling & 1 & 11 & 56 & look \\
\hline 2 & garage & spelling & 2 & 13 & 60 & garage \\
\hline 3 & Tell Who it is? & punctuation & 3 & 5 & 70 & Tell who... \\
\hline 4 & Tell Who it is? & punctuation & 3 & 5 & 70 & Tell who it is \\
\hline 5 & the marled & Spelling/ articles & 3 & 9 & 77 & market \\
\hline 6 & .....are in a day? & tense & 4 & 4 & 92 & ....are there \\
\hline 7 & .... are in half an hour? & tense & 4 & 4 & 92 & ... are there in a day? \\
\hline 8 & ...are in a minute? & tense & 4 & 4 & 92 & $\ldots$ are there in a minute? \\
\hline 9 & ... are in a lesson & tense & 4 & 4 & 92 & .... are there in a lesson? \\
\hline 10 & Six five & punctuation & 4 & 4 & 92 & six five \\
\hline 11 & Antarctica & spelling & 4 & 10 & 104 & Antarctica \\
\hline 12 & thinning & spelling & 4 & 11 & 105 & thin \\
\hline 13 & bold & spelling & 4 & 11 & 105 & bald \\
\hline 14 & Himalayas & spelling & 5 & 11 & 129 & Himalayas \\
\hline
\end{tabular}

TABLE (2)

SHOWS MISTAKES IN SPINE (3) THE PUPIL'S BOOK IN GENERAL

\begin{tabular}{|l|l|l|l|l|l|l|}
\hline No & Error & Type of mistakes & Unit & Lesson & Page & Correction \\
\hline 1 & the market & articles & 4 & 2 & 91 & market \\
\hline 2 & Ladies and gentlemen & punctuation & 4 & 4 & 94 & Ladies and gentlemen. \\
\hline 3 & The Red sea & punctuation & 4 & 6 & 99 & The Red Sea \\
\hline 4 & The great wall of China & punctuation & 4 & 6 & 99 & The Great Wall of China \\
\hline 5 & Cold wind cool down the clouds & agreement & 4 & 8 & 103 & Cold winds cool down the clouds \\
\hline 6 & Emirates & spelling & 4 & 13 & 119 & Emirates Faculty of Chemistry \\
\hline 7 & faculty & punctuation & 4 & 13 & 119 & Faculty of Chemistry \\
\hline 8 & "Guest of the day" & punctuation & 4 & 13 & 120 & "Guest of Day" \\
\hline 9 & Deck & punctuation & 5 & 2 & 125 & deck \\
\hline 10 & Bones & spelling & 5 & 3 & 127 & honest \\
\hline 11 & Turkish & spelling & 5 & 3 & 127 & Turks \\
\hline 12 & Desert & spelling & 6 & 2 & 157 & dessert \\
\hline 13 & Goalie & spelling & 6 & 2 & 158 & garlic \\
\hline 14 & sewing machine & spelling & 6 & 3 & 161 & sewing machine \\
\hline 15 & Can me..... & Punctuation & 6 & 7 & 179 & Can me.... \\
\hline 16 & Breath & Spelling & 6 & 8 & 181 & breathe \\
\hline 17 & Gradually & Spelling & 6 & 11 & 189 & gradually \\
\hline 18 & Rootles & Spelling & 6 & 11 & 189 & noodles \\
\hline 19 & The Sea view & Punctuation & 6 & 11 & 189 & The Sea View \\
\hline 20 & Racquets & Spelling & 6 & 11 & 190 & racquets or rackets \\
\hline
\end{tabular}


TABLE (3)

SHOWS MISTAKES IN SPINE (4) IN GENERAL:

\begin{tabular}{|c|c|c|c|c|c|c|}
\hline No & Error & Type of mistakes & Unit & Lesson & Page & Correction \\
\hline 1 & bamboo & spelling & 1 & 2 & 5 & bamboo \\
\hline 2 & exercise & spelling & 1 & 2 & 8 & exercise \\
\hline 3 & Iron sheet & Spelling & 1 & 2 & 8 & sheet iron \\
\hline 4 & Tea tab & Spelling & 1 & 3 & 11 & Tea table \\
\hline 5 & refrigerator & Spelling & 1 & 4 & 13 & refrigerator \\
\hline 6 & filling cabin & Spelling & 4 & 13 & 13 & filing cabinet \\
\hline 7 & factories & Spelling & 1 & 5 & 14 & factories \\
\hline 8 & joint & Spelling & 1 & 9 & 27 & join \\
\hline 9 & vinegar & Spelling & 2 & 3 & 38 & vinegar \\
\hline 10 & bandage & Spelling & 2 & 3 & 38 & bandage \\
\hline 11 & sleeves & spelling & 2 & 5 & 44 & sleeves \\
\hline 12 & greyhound & spelling & 2 & 6 & 48 & greyhound \\
\hline 13 & ingest & spelling & 2 & 10 & 59 & longest \\
\hline 14 & paragraph & spelling & 2 & 10 & 60 & paragraph \\
\hline 15 & sentences & Spelling & 2 & 1 & 60 & sentences \\
\hline 16 & question & Spelling & 2 & 10 & 60 & Question \\
\hline 17 & hampered & Spelling & 2 & 11 & 60 & happened \\
\hline 18 & Joni & Spelling & 2 & 12 & 64 & Jane \\
\hline 19 & OREDER & Spelling & 3 & 3 & 72 & ORDER \\
\hline 20 & want & Spelling & 3 & 5 & 76 & wasn't \\
\hline 21 & weak & Spelling & 3 & 9 & 86 & week \\
\hline 22 & school & Spelling & 4 & 6 & 109 & school \\
\hline 23 & Conner & Spelling & 4 & 10 & 126 & Corner \\
\hline 24 & country side & Spelling & 4 & 12 & 134 & countryside \\
\hline 25 & home work & Spelling & 5 & 2 & 143 & homework \\
\hline 26 & cigarettes & Spelling & 5 & 2 & 143 & cigarettes \\
\hline 27 & February & Spelling & 5 & 5 & 154 & February \\
\hline 28 & Natal & Spelling & 5 & 6 & 158 & Natal \\
\hline 29 & Michael & Spelling & 5 & 6 & 159 & Michael \\
\hline 30 & tiding & Spelling & 5 & 6 & 16 & tidings \\
\hline 31 & confirmed & Spelling & 5 & 8 & 165 & confirmed \\
\hline 32 & round about & Spelling & 5 & 8 & 166 & roundabout \\
\hline 33 & vocation & Spelling & 6 & 1 & 180 & vacation \\
\hline 34 & holly Quran & Spelling & 6 & 8 & 207 & Holy Quran \\
\hline
\end{tabular}

TABLE (4)

SHOWS MISTAKES IN SPINE (5) IN THE PUPIL'S BOOK IS IN GENERAL

\begin{tabular}{|l|l|l|l|l|l|}
\hline No & Error & Type of mistakes & Chapter & Page & Correction \\
\hline 1 & Family society and community & Punctuation & 1 & 1 & Family, society and community \\
\hline 2 & Doubled Letters With verbs & Punctuation & 1 & 9 & Doubled Letters with Verbs \\
\hline 3 & The Life of a mechanic & punctuation & 2 & 21 & The Life of a Mechanic \\
\hline 4 & $\begin{array}{l}\text { First, it is situated near a big market } \\
\text { which makes it easy for... }\end{array}$ & punctuation & 2 & 22 & $\begin{array}{l}\text { First, it is situated near a big market, } \\
\text { which makes it easy for... }\end{array}$ \\
\hline 5 & Women Issues and concerns & Punctuation & 1 & 37 & Women Issues and Concerns \\
\hline 6 & Arch, for example is both.... & Punctuation & 3 & 38 & Bear, for example, is both. \\
\hline 7 & $\begin{array}{l}\text { Bare, for example is both, nutritious } \\
\text { drink and good for satisfying thirst }\end{array}$ & Punctuation & 3 & 38 & $\begin{array}{l}\text { Bare, for example, is both nutritious } \\
\text { drink and good for satisfying thirst }\end{array}$ \\
\hline 8 & Al Nada Girls secondary School & Punctuation & 3 & 39 & Al Nada Girls' secondary School \\
\hline 9 & breath & Spelling & 5 & 69 & breathe \\
\hline
\end{tabular}


TABLE (5)

SHOWS ERRORS IN SPINE (6) IN THE PUPIL'S BOOK IS IN GENERAL

\begin{tabular}{|l|l|l|l|l|l|}
\hline No & Error & Type of error & Chapter & Page & Correction \\
\hline 1 & $\begin{array}{l}\text { The Gerund as a Noun and } \\
\text { Adjective }\end{array}$ & in-form & 5 & 73 & The Gerund as a Noun \\
\hline 2 & Increasing amount & in-form & 5 & 73 & 'Increasing ' is present participle not a gerund. \\
\hline 3 & Surprising number & in-form & 5 & 73 & 'Surprising' is present participle not a gerund \\
\hline 4 & Exciting idea & in-form & 5 & 73 & 'Exciting' is present participle not gerund. \\
\hline 5 & aging parents & in-form & 5 & 73 & 'Aging' is present participle not gerund. \\
\hline 6 & $\begin{array}{l}\text { The Gerund can be used as } \\
\text { a noun or adjective }\end{array}$ & in-form & 5 & 73 & $\begin{array}{l}\text { The gerund can be used as a noun but not as an } \\
\text { adjective. }\end{array}$ \\
\hline 7 & welcoming smile & in-form & 5 & 74 & 'welcoming' is present participle not a gerund \\
\hline 8 & $\ldots$. situation & in-form & 5 & 74 & $\begin{array}{l}\text { The in -form that precedes (excuse) must be } \\
\text { present participle. }\end{array}$ \\
\hline 9 & $\ldots .$. situation & in-form & 5 & 74 & $\begin{array}{l}\text { The in-form that precedes (situation) must be } \\
\text { present participle. }\end{array}$ \\
\hline 10 & $\ldots$..results & in-form & 5 & 74 & $\begin{array}{l}\text { The in-form that precedes (results) must be } \\
\text { present participle }\end{array}$ \\
\hline 11 & $\ldots .$. experience & in-form & 5 & 74 & $\begin{array}{l}\text { The in-form that precedes (experience) must be } \\
\text { present participle. }\end{array}$ \\
\hline 12 & $\ldots .$. number & in-form & 5 & 74 & $\begin{array}{l}\text { The in-form that proceeds (nimbler) must be } \\
\text { present participle. }\end{array}$ \\
\hline 13 & surds & Spelling & 8 & 126 & swords \\
\hline 14 & so he tired & Spelling & 10 & 169 & so he was tired \\
\hline
\end{tabular}

\section{REFERENCES}

[1] Ariel , M.(2008) . Pragmatics and Grammar. Cambridge: Cambridge University Press.

[2] Brown, P. and Levinson, S.( 1978). University in Language Usage: Politeness Phenomena. In E.Goody (ed.) Questions and Politeness: Strategies in Social Interaction. Cambridge: Cambridge University.

[3] Cormier, B. (1976). Aspect. Cambridge: Cambridge University Press.

[4] Connor, U. (1996). Contrastive Rhetoric. Cambridge: Cambridge University Press.

[5] Cooren F.(2010). Figures of Communication and Dialogue: Passion, Ventriloquism and Incarnation in Intercultural Pragmatics Vol. 7 No.1. Walter de Gruyter.

[6] Davidson, D.(1964). Concise American Composition and Rhetoric. New York: Charles Scribner's Sons.

[7] Fillmore, C. J. (1971). Toward a Theory of Deixis. The PCCLLU Papers (Department of Linguistics, University of Hawaii), 3.4., 219-41.

[8] Filmore, C.J.(1975). Santa Graz Lectures on Deixis. Mimeo, Indiana University Linguistics Club.

[9] Francis, D.S. J.Dinneen. (1967). An Introduction to General Linguistics: New York: Holt, Rinehart and Winston.

[10] Harris, R. (2005). Deixis in memory for Verb tense. Web Transcription Tool.. :linkinghub.elsevier.com/retrieve/pii/50022537173800388

[11] Hedge, T. (2000). Teaching and Learning in the Language Classroom. Oxford: Oxford University Press.

[12] Harford, J. and Heasely, B. (1993). Semantics: a Course book. Cambridge: Cambridge University Press.

[13] Irvine J. T.(1979). Formality and Informality in Speech Events. American Anthropologist, 81.4.773.99.

[14] Johnson, k (1971). Why are Foreign Students Incoherent. In Holden, S. (ed.) English for Specific Purposes. Modern English Publications. LDT.

[15] Kaplan, David (1989): "Demonstratives," in J. Alma, H. Wet stein, and J. Perry (eds.), Themes from Kaplan. Oxford: Oxford University Press, pp. 481-563.

[16] Levinson, S. C. (1983). Pragmatics. Cambridge: Cambridge University Press.

[17] Morrow, k. (1971). Authentic Texts and ESP. In Holden, S. (ed.) English for Specific Purposes. Modern English Publications LDT.

[18] Mustafa Shazali. (2011). Presupposition as a Pragmatic Inference - Toward a New Conceptualization of the Term in International Journal of Business and Social Science. Vol. 2, No. 2 . U.S.A: Centre for Promoting Ideas

[19] Oxford, R. L. (1990). Language Learning Strategies: What Every Teacher Should Know. Boston, Mass: Heinle\&Heinle.

[20] Prabhu, N.S. (1987). Second Language Pedagogy. Oxford: Oxford University Press.

[21] Searle, J. R. (1969). A Speech Acts. Cambridge: Cambridge University Press.

[22] Widdowson H. G, (1979). Explorations in Applied Linguistics. Oxford: oxford University Press.

Mustafa Shazali Mustafa Ahmed was born in a small town (Abu-Hamad) in northern Sudan in 7/10/1963. He has studied the preliminary, Intermediary and secondary in small town (Atabra). He got his bachelor degree from Atabra College of Education (English language education) in 1987. He got his M. A (1994) and his Ph. D (2004) from the University of Khartoum in Sudan in English language.

He has been positioned in many academic posts. He has undertaken the responsibility as a Dean of Islamic and Arabic studies for temporary times. A Coordinator and a permanent member in the graduate Council of Nile Valley University in the period (19941999). Now He is the Head of English Department and a member of the Graduate College/ English Committee. He has some local and International publications. Some of these publications are the following: (1) English Language as a Requirement Course for 
Information Students- in the journal of English Language Teaching vol .2, No. 3, September 2009- Canadian Centre of science and Education. (2) Educational Research Contents and Objectives: An Empirical Study on the Schools of River Nile State - Sudan. Published in IJBSS on January 22, 2011 Vol. 2 No. 2 Available in http://www.ijbssnet.com/current.html (3) Presupposition as a Pragmatic Inference - Toward a New conceptualization of the Term. Published in IJBSS on march 22, 2011. Vol.2. No. 7. ( Available in http://www..ijbssnet.com/current.html). (4) Factors Hampering Scientific Research in Sudan University - With Reference to problem formulation and Hypotheses. Published in IJHSS in April, 2011. Vol. 1, No 4, (Available in http://www.ijhssnet.com/index.php?option=com_content\&view=article\&id=85\&Itemid=9

Dr. Mustafa Shazali Mustafa Ahmed is a member in Association of Sudanese Teachers of English. 